\title{
The Significant Effect of Interface Shear Strength Between Soil Liner and Geotextile with Different Percentages of Bentonite and Sodium Bentonite with Geosynthetic
}

\author{
Roslizayati Razali ${ }^{1, *}$, Nor Azizah Che $\mathrm{Azmi}^{2}$, Diana Che Lat ${ }^{3}$, Mazidah Mukri ${ }^{4}$ and Farah \\ Hafifie Ahamad $^{5}$ \\ 1,2,3,5 Lecturer, Department of Geotechnical and Transport, Faculty of Civil Engineering, Mara \\ University of Technology, Malaysia \\ ${ }^{4}$ Senior Lecturer, Department of Geotechnical and Transport, Faculty of Civil Engineering, Mara \\ University of Technology,41450 Shah Alam, Malaysia
}

\begin{abstract}
This research focuses on the interface shear performance between geotextile and soil with various percentages of bentonite and sodium bentonite for landfill stability by using Direct Shear Test. Admixtures are mixed with clay to improve its performance as a liner material due to their ability to fill the voids between soil particles and also the most effective sealants. The aim of this study is focused on evaluating the effectiveness of bentonite and sodium bentonite on improving interface shear strength of fine soil. In this study, direct shear box was used to measure the interface shear strength of soil with different percentages of bentonite and sodium bentonite at optimum moisture content. Analysis shows that the most suitable percentage is of $5 \%$ of bentonite and $2.5 \%$ of sodium bentonite due to the highest interface shear strength of the mixture with geosynthetic. It is clearly shown that $2.5 \%$ sodium bentonite is the most suitable percentage to be used as admixture for landfill stability as it gives higher interface shear strength.
\end{abstract}

\section{Introduction}

Landfills have been the most common methods of organizing waste disposal. In most cases, open dumping is being practiced and takes place at about $50 \%$ of the total landfills. In addition, many landfills have been opted to be closed rather than setting up the new ones while the quantity of waste generated yearly is much faster than the natural degradation process [1]. The long term problems caused by landfill are related to the generation of leachate which can cause considerable environmental problems. Leachate is a highstrength wastewater formed as a result of percolation of rain-water and moisture through waste in landfills [2]. Leachate from solid - waste has been found to contain a number of heavy metals. During the formation of leachate, organic and inorganic compounds are transferred

\footnotetext{
* Corresponding author: roslizayati440@johor.uitm.edu.my
} 
from waste to the liquid medium [3] and pose hazardous effects to the receiving water bodies and thereby pose a potential threat to human health. In order to accomplish this, it is necessary to restrict the flow of water through the upper and lower boundaries of the landfill, referred to as the cover and the base liner of the landfill (McCartney et al., 2002). Recently, geosynthetic clay liner (GCLs) provides an alternative to compacted clay liners [6]. It has been used to replace and reduce the thickness of compacted clay liners (CCLs) required in composite liner or cover systems for waste containment (Eid and Stark, 1998). Due to the importance of the interface shear strength between geotextile and residual soil mixed with adhesive bentonite, this study is conducted to determine the difference of interface shear strength between geotextile and clay with different percentage of bentonite and sodium bentonite. A unique characteristic of sodium bentonite is that it can draw water from adjacent soils, possibly reaching water contents in excess of 100 percent [6].

\section{Scope of Study}

To achieve the objectives of this study, a stage of laboratory work has been performed so that the result can be presented systematically. All the standard tests were conducted based on British Standard as references. The basic laboratory tests that have been performed are Particle Size Distribution, Particle Density Test and Atterberg Limit which includes Plastic Limit $(P L)$ and Liquid Limid $(L L)$ in order to determine the Plasticity Index $(P I)$. Inaddition, specific gravity test, shrinkage limit test and $\mathrm{pH}$ test were also included in this study. All of the basic properties tests excluding Particle Size Distribution were performed repeatedly with different percentage of bentonite and sodium bentonite. After all of the test have been conducted, soil samples were prepared and mixed together using various percentages of bentonite and sodium bentonite $(2.5 \%, 5 \%, 7.5 \%$ and $10 \%)$ to get the best value of optimum moisture content of the admixtures using Standard Proctor Test. The value was used for the preparation of remoulded samples for direct shear test. The shear box is normally the most preferred method for soil shear testing because it is a fast and economical method of measuring shear strength. A specimen is placed in a shear box which has two stacked halves to hold the sample; the contact between the two halves is at approximately the mid-height of the sample. Soil without admixture at the top, bound by geotextile at the middle and soil with the admixture (bentonite or sodium bentonite) is placed at the bottom half of the apparatus. Geotextile and soil with admixture were placed exactly at the failure plane. A normal load was applied to the specimen and the specimen was sheared across the pre-determined horizontal plane between the two halves of the shear box. The size of the shear box used is $60 \mathrm{~mm} \times 60 \mathrm{~mm}$, which can give a more efficient result for soil shear strength as stated by Ingold (1982).

\section{Theoretical background}

Over the past few years, different geosynthetics manufacturers have proposed several unique GCL products that attempt to minimize hydraulic conductivity while maximizing shear strength [7]. Throughout the years, geosynthetic clay liners(GCLs) has been increasingly selected to replace compacted clay liners (CCLs) in composite liner and cover systems for waste containment facilities (Stark, 1998). GCLs are prefabricated geocomposite materials used in hydraulic barriers as an alternative to compacted clay liners due to their affordability and excellent barrier performance against contaminants. During the landfill construction, there are some critical element parts that need to be considered. One of the critical parts in this stage is when designing the landfill slope. Hence, engineers are required in designing slope which is safe in terms of not exceeding the safe slope angle 
for liner components, internal properties and their respectiveinterface parameters within the system (Saravanan et al, 2004). In this study, various admixtures of bentonite and sodium bentonite were used in order to determine the significant effect of interface shear strength between soil liner and geotextile with different percentages of admixtures.

\section{Test Result and Discussion}

Each sample has been processed at the laboratory accordance with British Standard Method - BS1377: Part 2. Table 1 and 2 show the list of basic properites of the soil.

Table 1: List of the basic properties tests of soil with different percentages of bentonite.

\begin{tabular}{|l|l|l|l|l|l|l|}
\hline Sample & $\begin{array}{l}\text { SG } \\
(\mathrm{Mg} / \mathrm{m} 3)\end{array}$ & LL (\%) & PL\%) & PI (\%) & PH & SL (mm) \\
\hline SL-B & 2.4 & 44.26 & 37.59 & 7 & 3.96 & 1.23 \\
\hline SL-2.5B & 2.25 & 64.24 & 42.31 & 22 & 4.22 & 3.13 \\
\hline SL-5B & 2.42 & 66.03 & 43.99 & 22 & 4.63 & 5.73 \\
\hline SL-7.5B & 2.47 & 68.16 & 46.88 & 21 & 4.83 & 7.33 \\
\hline SL-10B & 2.49 & 72.35 & 48.64 & 24 & 5.4 & 7.93 \\
\hline
\end{tabular}

Table 2: List of the basic properties tests of soil with different percentages of sodium bentonite

\begin{tabular}{|l|l|l|l|l|l|l|}
\hline Sample & $\begin{array}{l}\text { SG } \\
(\mathrm{Mg} / \mathrm{m} 3)\end{array}$ & LL (\%) & PL $\%)$ & PI (\%) & PH & SL (mm) \\
\hline SL-SB & 2.4 & 44 & 38 & 6 & 3.96 & 11.67 \\
\hline SL-2.5SB & 2.46 & 63 & 49 & 14 & 4.37 & 13.33 \\
\hline SL-5SB & 2.44 & 54 & 37 & 17 & 4.76 & 14 \\
\hline SL-7.5SB & 2.6 & 61 & 48 & 12 & 5.15 & 15.67 \\
\hline SL-10SB & 2.62 & 65 & 45 & 20 & 5.28 & 16 \\
\hline
\end{tabular}

The results show that the increasing percentages of the bentonite and sodium bentonite give higher plasticity of the soil. The presence of bentonite in the soil gives the chances for more water to retain at the condition of suction. It was proved by Osinubi and Amadi in 2010 where in their previous studies, it was shown that liquid limit is increased in increasing of bentonite. When bentonite is added to the soil, it displays a clayey nature at relatively high water contents. Bentonite which contains swelling clay minerals such as montmorillonite is inferred to expand and fill the voids in the buffer and backfill materials (Komine and Ogata, 1996). In addition, it is proved that the presence of bentonite reduces the acidity of the natural soil and this is proven by Zanzinger et. al in 2002 [11], where bentonite typically have the value of $\mathrm{pH} 9$ or more.

\section{Compaction test}

Proctor standard compaction test, according to BS 1377-1990: Part 4 was applied to determine the maximum dry density (MDD) and the optimum moisture content (OMC) for all samples added with bentonite and sodium bentonite. It is observed from Fig. 1 that the percentage of optimum water content is increased relatively with the increased percentage of bentonite whereas Maximum Dry Density (MDD) is decreased slightly with the increased percentage of bentonite. Chalermyanont [12] stated that with more bentonite added, the optimum water content increases and maximum dry density decreases. Fig. 2 
shows the combination of compaction curve added with sodium bentonite and it could be clearly seen that by adding sodium bentonite to the soil samples, the Maximum Dry Density (MDD) increases as compared to blank sample.

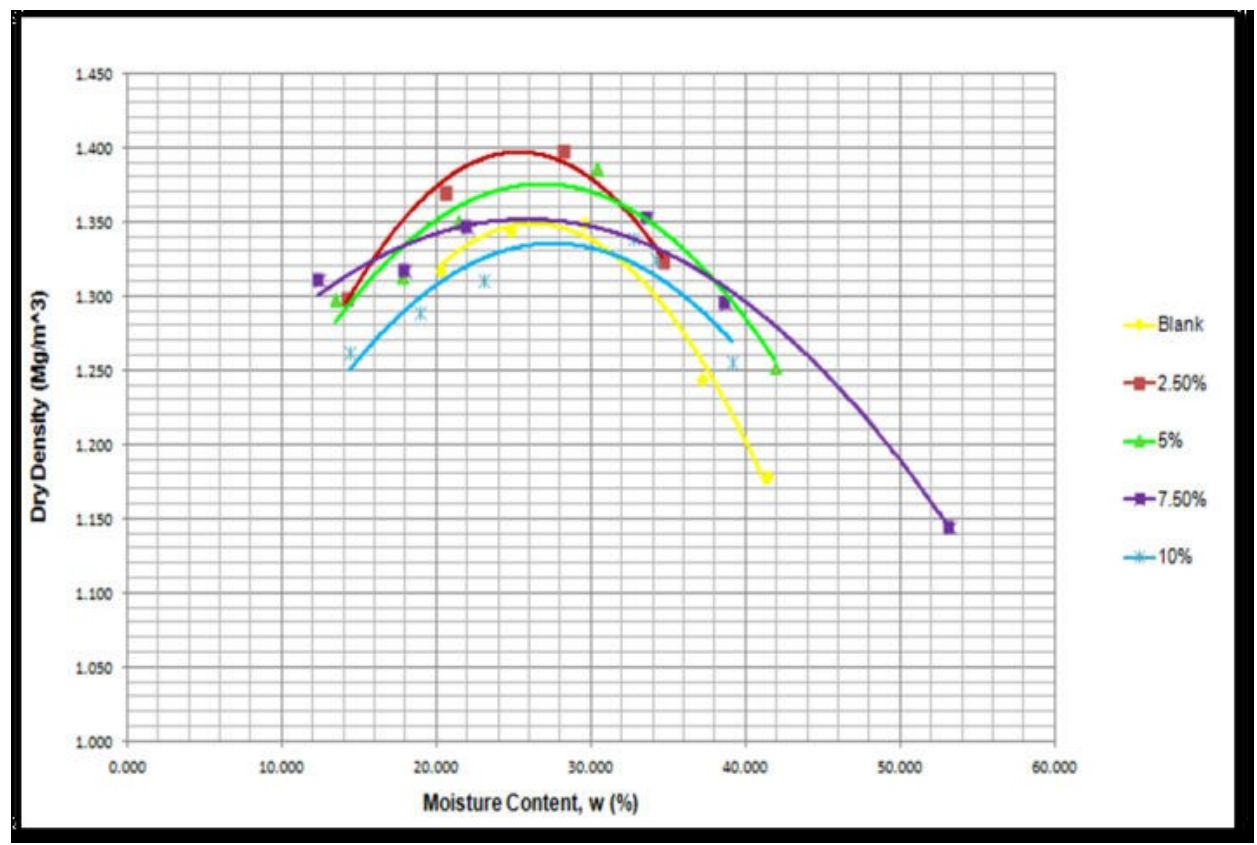

Fig.1: The combination of Maximum Dry Density against Optimum Moisture Content

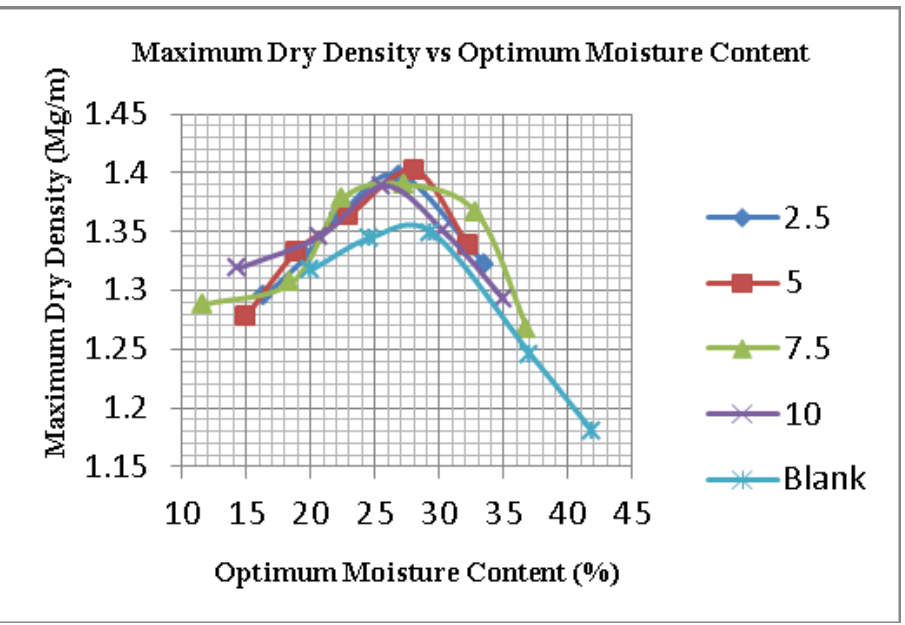

Fig. 2: The combination of Maximum Dry Density against Optimum Moisture Content 


\section{Shear box test}

The size of shear box use in this study is $60 \mathrm{~mm} \times 60 \mathrm{~mm}$. Soil at top is to bound by geotextile at the middle and clay with the admixture (bentonite or sodium bentonite) is placed at the bottom part of the apparatus (Fig. 2.0). Geotextile and soil with admixture are placed exactly at the failure plane. The geotextile is wrapped on the surrounding upper area of the shear box to ensure that there is no folding of the geotextile during the shearing stage. Direct shear Test was performed with applied normal stress of $100 \mathrm{kPa}, 200 \mathrm{kPa}$ and $300 \mathrm{kPa}$ for both samples of bentonite and sodium bentonite. Fig. 3 until Fig. 7 show five (5) samples prepared using the optimum moisture content that was obtained from the compaction tests. The graphs below present the relationship between Shear Stress and Horizontal Displacement of bentonite for SL-B, SL-2.5B, SL-5B, SL-7.5B and SL-10B.

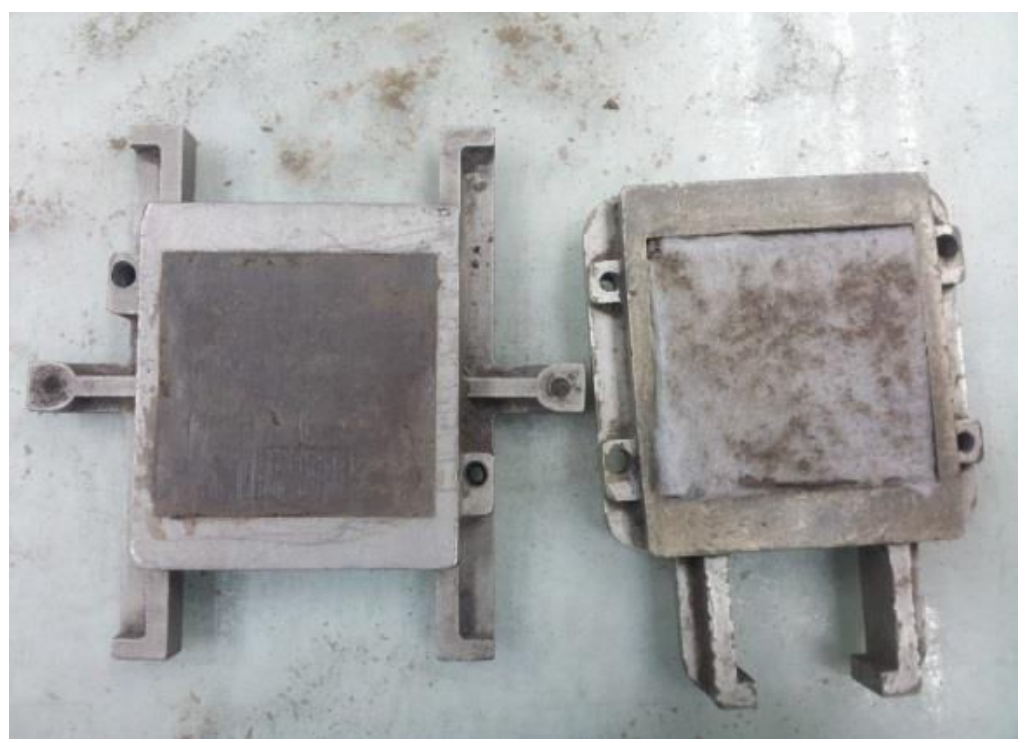

Figure 2.0 sample preparation

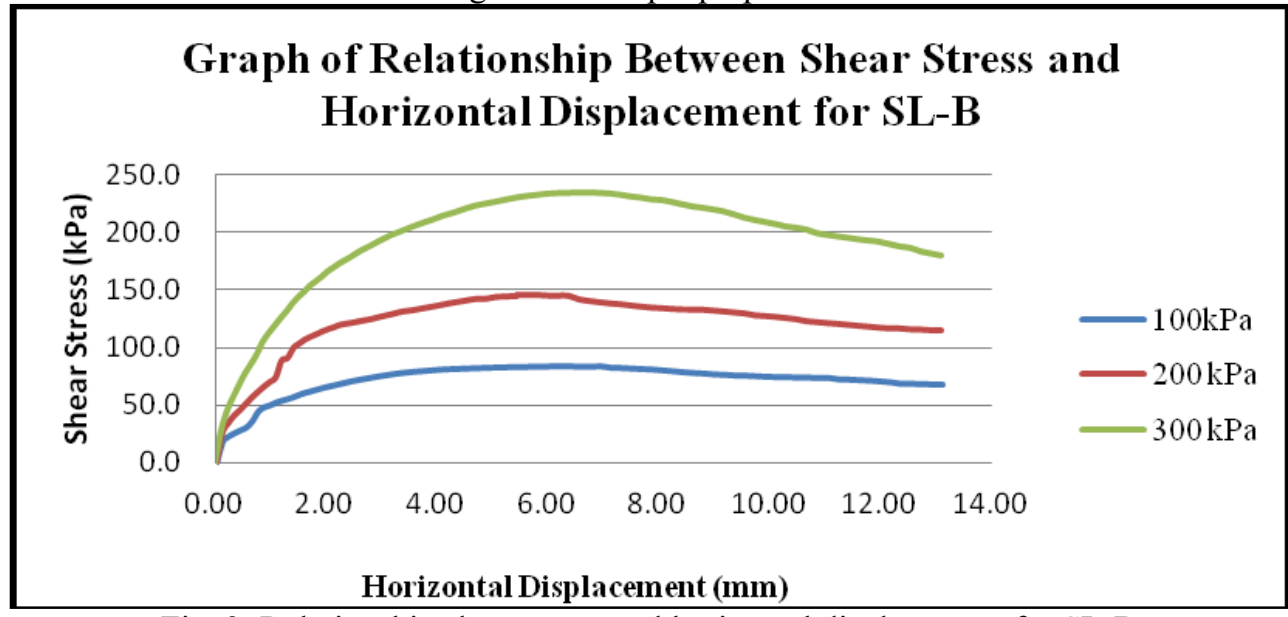

Fig. 3: Relationship shear stress and horizontal displacement for SL-B 


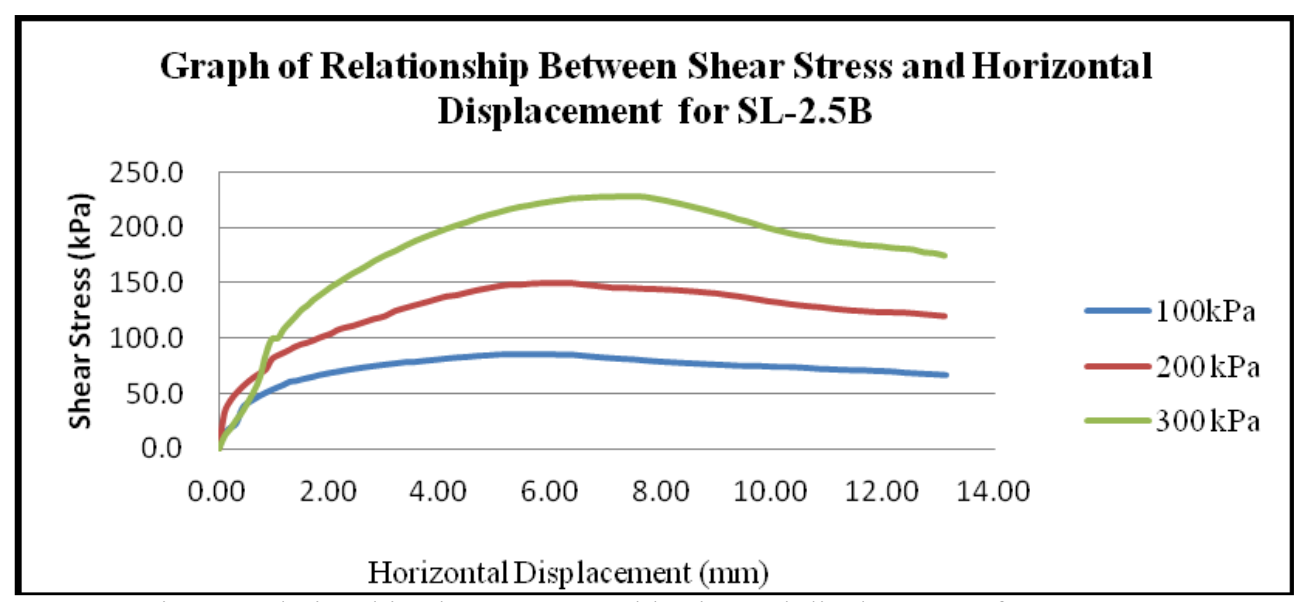

Fig. 4: Relationship shear stress and horizontal displacement for SL- 2.5B

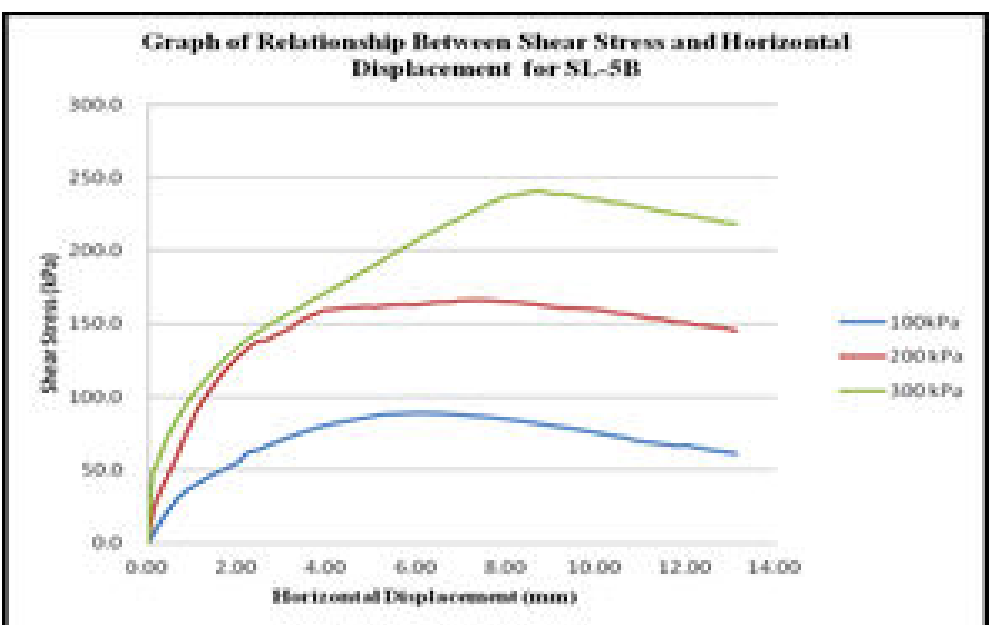

Fig. 5: Relationship shear stress and horizontal displacement for SL- 5B

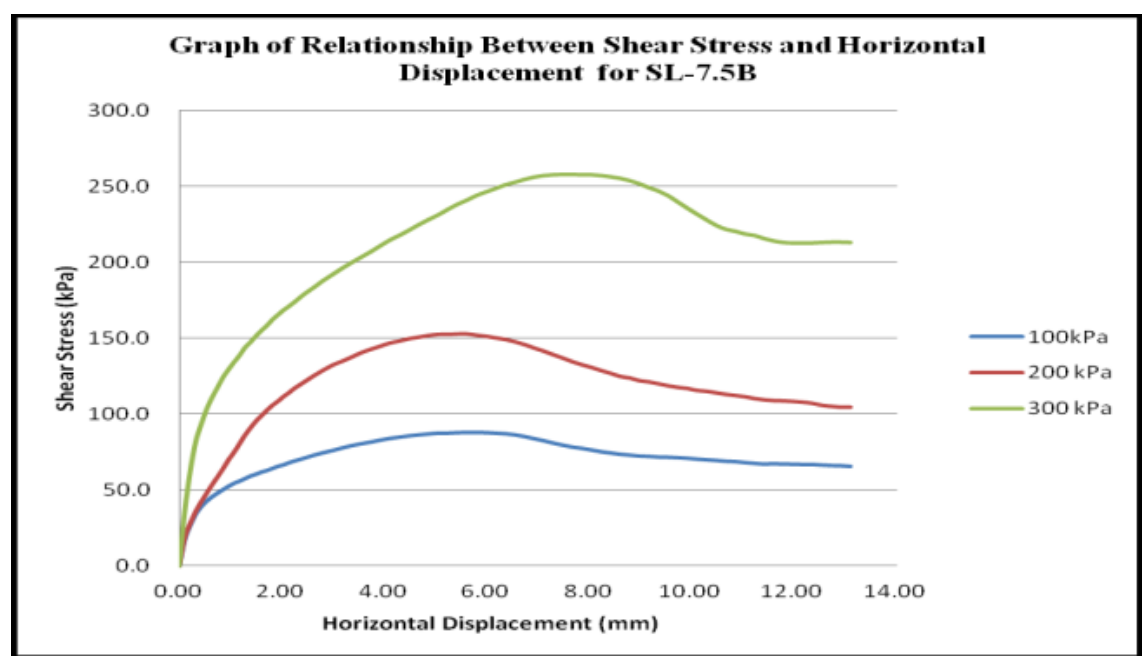

Fig. 6: Relationship shear stress and horizontal displacement for SL-7.5 B 


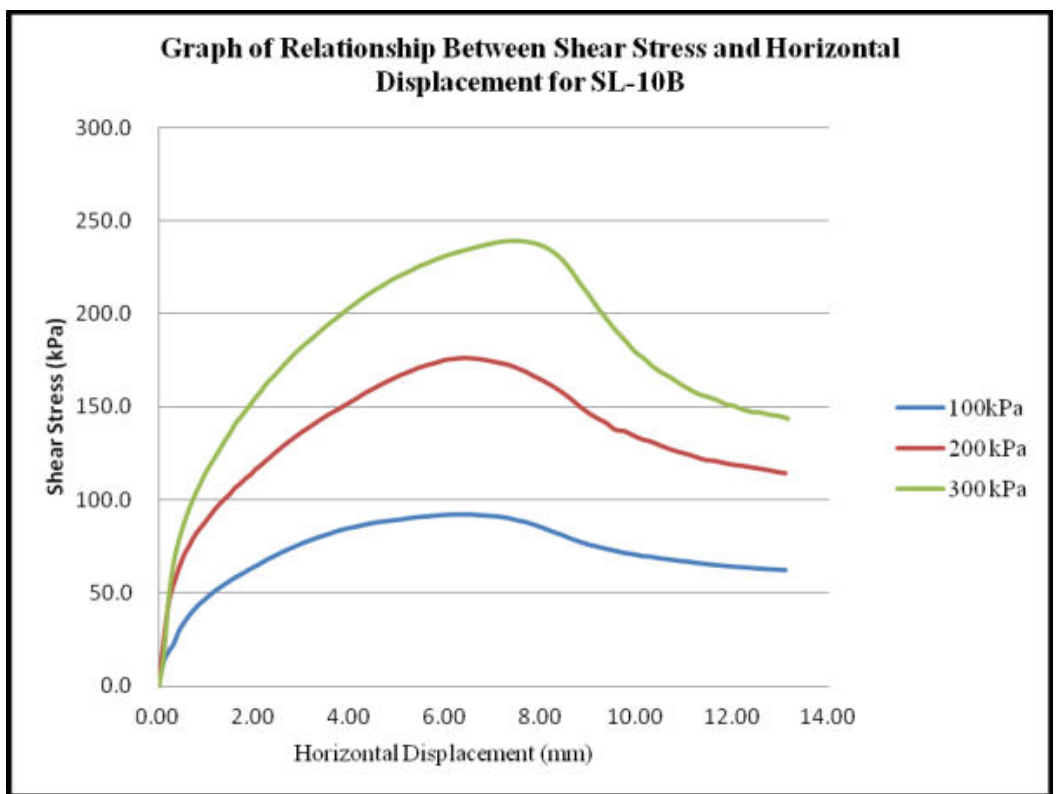

Fig. 7: Relationship shear stress and horizontal displacement for SL-10B

Based on the maximum value of shear stress with applied normal stress, graph of cohesion and internal angle can be determined. The summary of cohesion and friction angle of the soil is presented in Table I. From the result, the presence of bentonite in the soil did not give a serious impact on the cohesion value and the angle of interface friction between samples and the geotextile. Based on the result, cohesion angle without bentonite gives the minimum value of cohesion and friction angle which are $10.85 \mathrm{kPa}$ and $35.16^{\circ}$. The increasing of bentonite showed the increment until the additional of $5 \%$ of the additive. However, there is a limitation for bentonite content beyond which is indicated by the drop of parameters after $7.5 \%$ of the bentonite content due to the reaching of optimum limit of bentonite added to the soil. The increase in the percentage of bentonite can help in increasing the cohesion and friction angle for the tested samples of SL-2.5B and SL- 5B up to $37.24^{\circ}$ for friction angle and $13.29 \mathrm{kPa}$.

Table I: Cohesion and Friction value for Bentonite

\begin{tabular}{|c|c|c|}
\hline Sample & $\boldsymbol{\emptyset}^{\circ}$ (degree) & $\mathbf{C}(\mathbf{k P a})$ \\
\hline SL-B & 35.16 & 10.85 \\
\hline SL-2.5B & 35.45 & 12.45 \\
\hline SL-5B & 37.24 & 13.29 \\
\hline SL-7.5B & 36.80 & 12.54 \\
\hline SL-10B & 36.60 & 12 \\
\hline
\end{tabular}

Fig. 9 until Fig. 13 below present the relationship of Shear Stress and Horizontal Displacement of sodium bentonite for SL- 0SB, SL-2.5SB, SL-5SB, SL-7.5SB and SL 10SB. This test was performed with applied normal stress $100 \mathrm{kPa}, 200 \mathrm{kPa}$ and $300 \mathrm{kPa}$. The normal stress was kept constant during test and the maximum value of shear stress can be measured during the direct test. 


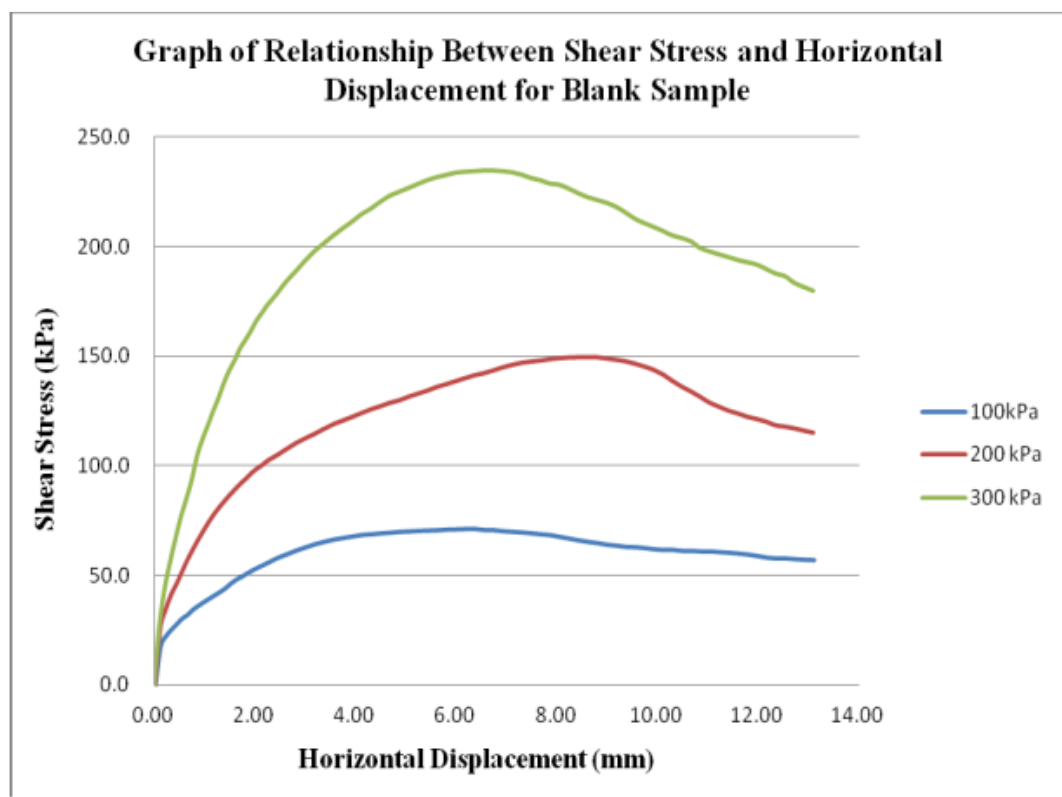

Fig. 9: Relationship shear stress and horizontal displacement for SL-0SB

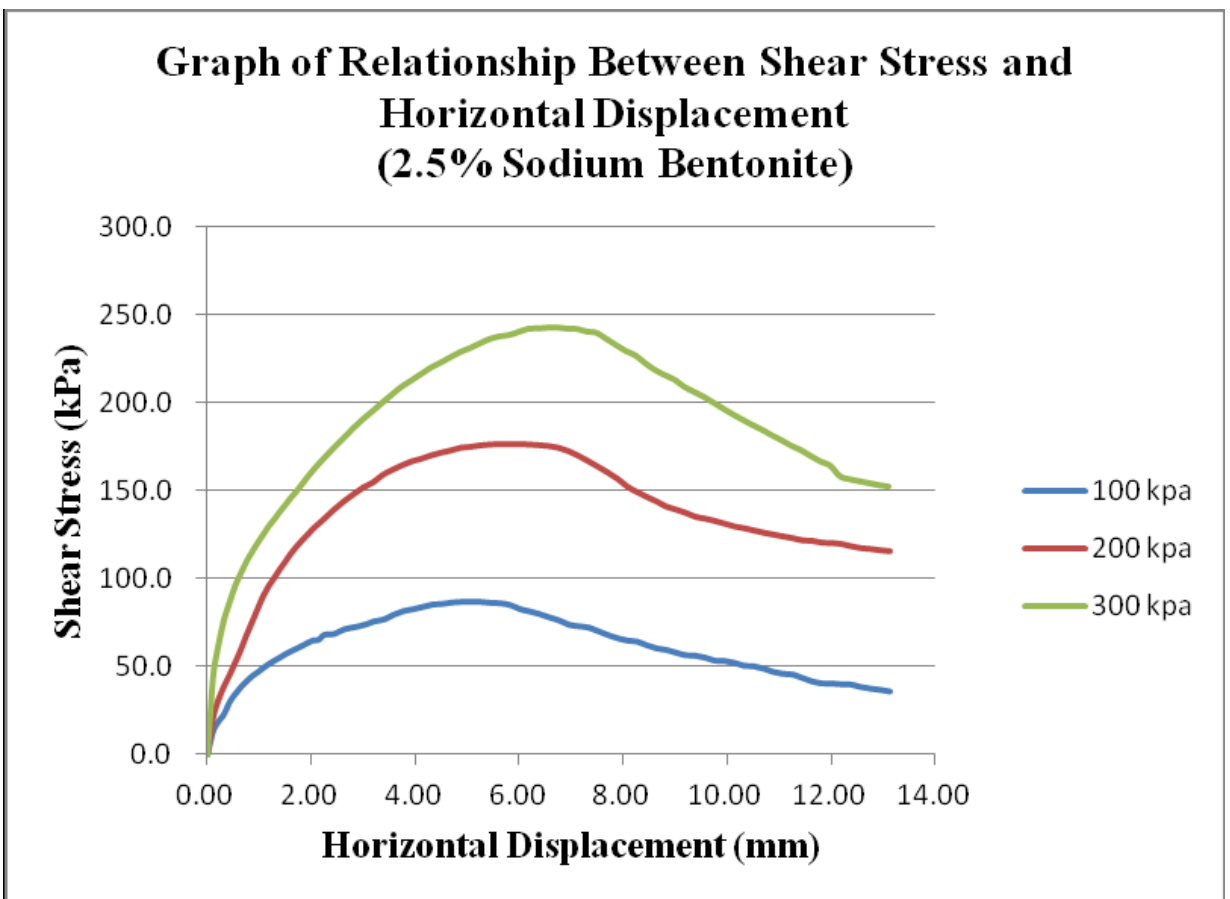

Fig. 10: Relationship shear stress and horizontal displacement for SL-2.5S B 


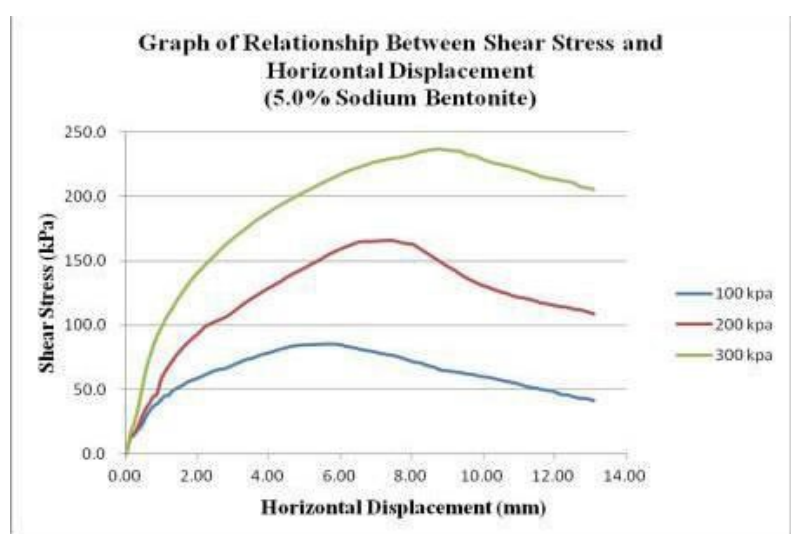

Fig. 11: Relationship shear stress and horizontal displacement for SL-5SB

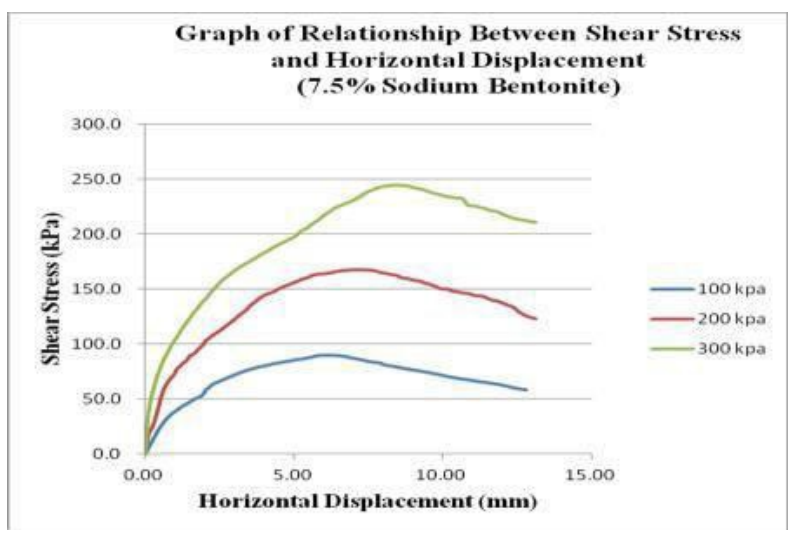

Fig. 12: Relationship shear stress and horizontal displacement for SL-7.5SB

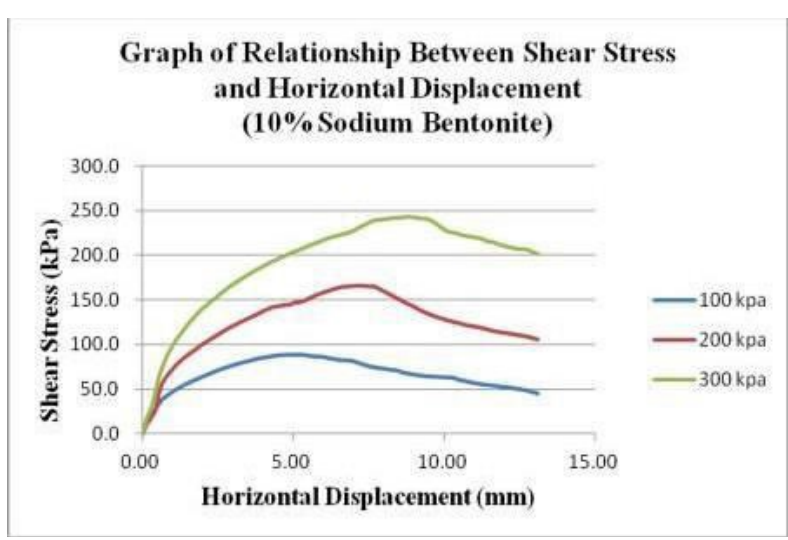

Fig. 13: Relationship shear stress and horizontal displacement for SL-10SB

Based on Table 2, it shows that the higher value for $\mathrm{c}$ is at soil added with $2.5 \%$ of sodium bentonite that gives the value of $12.35 \mathrm{kPa}$ and friction of $37.95 \%$. As for the rest, the soil that was added with $10 \%$ of sodium bentonite is found to produce the lowest value for c with $11.27 \mathrm{kPa}$ and friction of $37.70 \%$. It can be said that the more sodium bentonite were added to the soil, the lower the shear strength tend to be, due to the swelling of the soil. It can be presumed that the cohesion value from the result is insignificant as the shear 
between soil and geotextile will affect the movement of the soil particle. Only natural soil sample gives lower value of cohesion but the other samples give quite similar value for cohesion. Apart from that, the value for the friction angles did not show any apparent change with the increasing percentage of sodium bentonite, and the result is quite similar to each other.

Table II: Cohesion and Friction value for sodium Bentonite

\begin{tabular}{|c|c|c|}
\hline Sample & ${ }^{\circ}$ (degree $)$ & $\mathrm{c}(\mathrm{kPa})$ \\
\hline SL-0SB & 10.63 & 36.3 \\
\hline SL-2.5SB & 12.35 & 37.95 \\
\hline SL-5SB & 11.43 & 37.07 \\
\hline SL7.5SB & 12.3 & 37.76 \\
\hline SL-10SB & 11.27 & 37.70 \\
\hline
\end{tabular}

From the parameters, the shearing resistance of the soil is calculated for applied normal stress of $100 \mathrm{kPa}, 200 \mathrm{kPa}$ and $300 \mathrm{kPa}$. Shearing resistance at failure for the tested samples shows in Table III.

Table III(a):Value of shear strength for Bentonite

\begin{tabular}{|c|c|c|c|c|c|}
\hline Norm $\begin{array}{c}\text { Shear strength } \\
\text { al } \\
\text { stress } \\
(\mathrm{kPa})\end{array}$ & \multicolumn{6}{|c|}{ SL-B } & $\begin{array}{c}\text { SL- } \\
2.5 \mathrm{~B}\end{array}$ & $\begin{array}{c}\text { SL- } \\
5 \mathrm{~B}\end{array}$ & $\begin{array}{c}\text { SL- } \\
7.5 \mathrm{~B}\end{array}$ & $\begin{array}{c}\text { SL- } \\
10 \mathrm{~B}\end{array}$ \\
\hline 100 & 81.2 & 83.6 & 89.3 & 87.3 & 86.2 \\
& 9 & 4 & & 5 & 7 \\
\hline 200 & 151. & 154. & 165. & 162. & 148. \\
& 73 & 85 & 32 & 16 & 53 \\
\hline 300 & 222. & 226. & 241. & 236. & 234. \\
& 16 & 04 & 33 & 97 & 8 \\
\hline
\end{tabular}

Table III(b): Value of shear strength for sodium bentonite 


\begin{tabular}{|c|c|c|c|c|c|}
\hline Norm & \multicolumn{5}{|c|}{ Shear strength $(\mathrm{kPa})$} \\
\cline { 2 - 6 } al & SL- & SL- & SL- & SL- & SL- \\
stress & OB & $2.5 S$ & $5 S B$ & $7.5 S$ & $10 S$ \\
$(\mathrm{kPa})$ & & B & & B & B \\
\hline 100 & 84.0 & 90.3 & 86.9 & 89.7 & 88.5 \\
& 9 & 4 & 8 & 6 & 6 \\
\hline 200 & 157. & 168. & 162. & 166. & 165. \\
& 54 & 33 & 52 & 10 & 85 \\
\hline 300 & 231 & 246. & 238. & 244. & 243. \\
& & 32 & 07 & 67 & 14 \\
\hline
\end{tabular}

In comparison to experimental results, it can be stated that the increment percentage of additives added give different value of shear strength. Maximum value of shear strength tested at $100 \mathrm{kPa}, 200 \mathrm{kPa}$ and $300 \mathrm{kPa}$ applied normal stress when added with $5 \%$ bentonite (SL-5B) and shear strength start to drop after that. However, based on the result that has been conducted for sodium bentonite, the best value of shear strength reach at $2.5 \%$ of sodium bentonite added ( $\mathrm{SL}-2.5 \mathrm{SB})$ and start to decrease after more sodium bentonite is added.

\section{Conclusion}

Based on the findings and data of physical properties and engineering properties, the increase of the percentages of bentonite and sodium bentonite tends to increase the liquidity Index of fine soil. For compaction test, the percentage of optimum water content is increased relatively with increasing bentonite but given vice versa result for the value of the Maximum Dry Density (MDD). In case of sodium bentonite, the result for compaction test did not give good relationship to the soil as the optimum moisture content and Maximum Dry Density (MDD) are not consistent. In Direct Shear Test, it shows that even the presence of bentonite and sodium bentonite in the sample is proved to give higher interface shear strength to the tested soil, additional bentonite and sodium bentonite tend to decrease its shear strength. This may occur when increasing content of bentonite and sodium bentonite are added to the soil, increase in water content thus results in the decrease in density and shear strength. It shows that sodium bentonite is the most effective sealants and suitable for landfill stability as it gives higher interface shear strength compared to bentonite

\section{Acknowledgment}

The authors are thankful to Research Management Institute (RMI) University Technology MARA (UiTM0, for funding this paper and providing a place to carry out the experimental work. Also, special thanks to Dr Mazidah Mukri who has given numerous advices, information, encouragement, criticism and support during this research. In addition, special thanks to the laboratory staffs of Universiti Teknologi MARA (UiTM) for their valuable assistances in handling the laboratory equipment. 


\section{References}

1. Mohd Masirin, Mohd Idrus and Ridzuan, Mohd Baharudin and Mustapha, Shahabudin and Adon@Mohd Don, Rashidah, An overview of landfill management and technologies: a Malaysian case study at Ampar Tenang. In: 1st National Seminar on Environment, Development and Sustainability (PSISenviro2008), 28-29 July 2008, Selangor, Malaysia, (2008)

2. Hasar, H., Unsal, S. A., Ipek, U., Karatas, S., C nar, O., Yaman,C. and K nac, C. , Stripping/ flocculation/ membrane bioreactor/reverse osmosis treatment of municipal landfill leachate. Journal of Hazardous Materials, 171, 309-317, (2009)

3. Bohdziewicz, J., Neczaj, E. and Kwarciak, A., Landfill leachate treatment by means of anaerobic mem brane bioreactor, Desalination, 221, 559-565, (2008)

4. John Scott McMcartney, Jorge G. Zomberg and Robert H. Swan, Internal and Interface Shear Strength Of Geosynthetic Clay Liners (Gcls), (2002)

5. Stark, H. Eid. I, Shear Behaviour of an Unreinforced Geosynthetic Clay Liner. Geosynthetic International , 645- 658, (1998)

6. Daniel, D.E. Shan, H,Y,. And Anderson, J.D., Effects Of Partial Wetting on the Performance of the Bentonite Component Of Geosynthetic Clay Liners, Proceedings Of Geosynthetics'93, IFAI, Vol, 3, March 1993, Pp. 1483- 1496, (1993)

7. Bouazza, A., Geosynthetic Clay Liners, Geotextile and Geomembrane, 20, 3-17, (2002)

8. Stark, T.D., Williamson, T.A. and Eid, H.T., HDPE Geomembrane/Geotextile Interface Shear Strength, Journal of Geotechnical Engineering. ASCE. 122(3): 197-203, (1996)

9. Osinubi K.J \& Amadi A.A, Variations in Soil Water Characteristic Curves of Lateritic Soil Treated with Bentonite. Experimental and Applied Modellingog Unsaturated Soils, ASCE, (2010)

10. Komine, H., and Ogata, N. "Observation of swelling behaviour of bentonite by new electron microscope." Proc., 2nd Int. Congress on Environmental Geotechnics, 1, 563-568, (1996b)

11. Zanzinger, H., Koerner, M. \& Gartung, E., Clay Geosynthetic Barriers. Proceedings of International Symposium is [i.e. In] Nuremberg 2002, Nuremberg/Germany, 12-15, (2002)

12. Chalermyanont, T., \& Arrykul, S., Compacted Sand-Bentonite Mixtures for Hydraulic Containment Liners. Songklanakarin Journal Science and Technology , 315-322, (2005)

13. British standard institution, Method of test for soils for civil engineering purposes, BS 1377 - 1990 : Part 2 and 4, (1990) 